of the scope of biology, clearly recognized the need for some 6-8 professorial appointments together with a substantial number of non-professorial staff in order to establish a really effective unit for teaching and research in the biological sciences.

Department of Botany, University College of Swansea.

${ }^{1}$ Asimov, I., The Intelligent Man's Guide to Modern Science, 2, The Biological Sciences (Basic Books, New York, 1960).

${ }^{2}$ Commoner, B., Science, 133, 1745 (1961).

"Wyatt, H. V., Nature, 181, 960 (1961).

IF biologists wish to avoid "molecular biology", "in its extreme form", then we must devise courses that will attract potential physical scientists. Can we be complacent when biochemists are becoming more divorced from biology and when more of the better students study neither botany nor zoology? While I argued for experimental biology, at the same time I emphasized the greater need for studying live animals and plants: not only in field studies but also in the laboratory. It is not that our established biology lecturers are out of touch, but that our organization, syllabuses and examinations are. Because I believe that biology is relevant, I wish to see more physical scientists study it.

The memoranda of the Royal Society and of the professors of botany are both in private circulation; other biologists would be glad to read them.

Department of Bacteriology,

H. V. WYatT

University of Leeds.

\title{
CONQUEST OF HUNGER
}

\begin{abstract}
A SYMPOSIUM on food supply and population was an important feature at the meeting of the British Association for the Advancement of Science in 1960 in Cardiff. Papers bearing on this theme were delivered by a number of leading authorities, followed by discussions (see Nature, 188, 9; 1960). The papers have now been published by the British Association in a booklet called Hunger : Can it be Averted? edited by Sir John Russell and Dr. Norman C. Wright*. 'The booklet, with a preface by Sir John, contains the following articles: "The Current Food Supply Situation and Current Trends", by Dr. Norman C. Wright; "Population Prospects and their Implications", by Prof. D. V. Glass; "Economic Conditions for Greater Output", by Prof. W. A. Lowis; "Land Use and Food Production", by Prof. L. Dudley Stamp; "Industrial and Technological Needs", by Lord Fleck; "What Limits Food Production ?", by Prof. H. D. Kay; "Some Conclusions", by Prof. P. M. S. Blackett. There is an appendix, with seventeen figures, entitled "Vast Population Increases Intensify the Battle Agrinst Hunger".
\end{abstract}

The booklet presents the main facts about food supply and population lucidly and without emotional bias, as might be expected from the high status of the contributors. What are these facts? If world population continues to increase at the present rate it will double itself by A.D. 2000, and nothing likely to happen within the next few decades will reduce this rate of growth, due largely to 'death control', which will become steadily more effective. In fact, the rate of increase will probably accelerate as the expectation of life rises in the developing countries and the saving of child life-the field in which modern medicine and public health have achieved their most striking successes-produces a population structure particularly favourable to high fertility.

At present large numbers of people in the world are under-fed and badly fed, so that existing food supplies are inadequate. To feed the much larger population of $1980-2000$, much more food than is now being produced will be needed. The quantities required, at given levels of consumption, can be roughly estimated. Potentially, they can be made available by distributing surpluses, bringing new land

* Hunger : Can It Be Averted? Edited by Sir E. John Russell and Dr. Norman C. Wright. Pp. $v+80$. (London: British Association for the Advancement of Science, 1961.) 58. under cultivation and increasing yields. For economic and political reasons the contribution of surpluses is unlikely to be important. There are wide areas, at present unproductive, which can be brought under cultivation at greet effort and cost, but the most promising possibilities lie in increasing yields from land already under cultivation. Sufficient technical knowledge already exists to increase yields enormously in most parts of the world, and this knowledge is being extended year by year. There is plenty of dramatic evidence showing what can be achieved, for example, by using more fertilizers. It is a familiar fact that yields of rice in Japan are 3-4 times greater than in India, a difference due to the large amounts of inorganic fertilizers used in Japan, combined with improved seed varieties, controlled irrigation and efficient cultural practices. The crux of the matter is whether solutions can be found to the economic, political, social, educational and administrative problems which prevent technical knowledge from being effectively applied. As Prof. Blackett puts it: "to raise the low level of much of the indigenous agriculture and to bring under cultivation more of the abundant cultivable land requires a massive educational and social advanse combined with heavy capital investment in communications, housing, schools, agricultural implements, fertilizers, irrigation and drainage and, as Prof. Kay has pointed out, barbed wire". The key lies in the "massive educational and social advance".

Departments of agriculture in many countries are at present under-staffed and often ineffective, and great efforts are needed to establish extension services to bring modern techniques to cultivators. Food crops for local consumption usually receive less attention from agricultural departments than cash crops. Technical assistance to developing countries in fields concerned with food production should be given on a much greater scale. These and numerous other facts with an important bearing on the situation are discussed by the contributors.

While the booklet deals adequately with population trends and prospects, it does not go deeply into the basic issue of population control. It is primarily concerned with practical and inescapable problems of food supply and population which mankind must face in the near future. On these it says nearly all that can be said and much that has been said before. The picture is indeed clear enough. In the preface, 
Sir John Russell comments: "the broad conclusion was that hunger need not be feared for at least the next forty years and this result could be achieved on present knowledge if only it were properly applied. . . These optimistic conclusions from such an authoritative group come as a great relief after the pessimistic gloom that has long surrounded the subject". The booklet may not produce this impression on all its readers, who should be many.

W. R. Aykroyd

\section{PLANT PHENOLICS GROUP OF NORTH AMERICA}

$\mathrm{T}$ HE recent increase of interest in the biology and chemistry of the phenolic constituents of plants becomes immediately apparent on inspection of the lists of contents of many of the world's biological and chemical publications. However, workers in the various fields embraced by an interest in the plant phenolics are widely scattered throughout departments of botany, biology, biochemistry, chemistry, microbiology, pharmacy, pharmacology and forestry, in universitios, research institutes, government agencies and in industry. There is consequently almost no common meeting place for people with such interests, with the result that there is little discussion and exchange of information between workers of the different disciplines.

In 1956, the Plant Phenolies Group was founded in Great Britain as an informal organization with the aims of promoting "the advancement of the knowledge of phenolic and related constituents of plants in respect of their chemistry, function, biosynthesis, effect on plant and animal physiology and pathology, and the application of such knowledge in agriculture and industry". Since its founding the Plant Phenolics Group has been very successful in achieving these aims, holding two or three meetings a year. The proceedings of many of these meetings have been published.

At the ninth International Botanical Congress in Montreal in 1959, discussions with various biochemists and physiologists interested in plant phenolic substances led to the idea that a sister organization be formed in North America. The largest problem with forming such a group on this continent, of course, results from its geographical size, which would prohibit such a group from meeting more frequently than once a year.

An organizing committee, consisting of Dr. T. A. Geissman (University of California), Dr. V. C. Runeckles (Imperial Tobaceo Co. of Canada) and
Dr. G. H. N. Towers (McGill University), distributed a letter to interested persons in 1960 , the response to which was so enthusiastic as to encourage the committee to make plans for an inaugural meeting. This was held at Colorado State University, Fort Collins, during August 31-September 1, and took the form of a symposium on the biochemistry of plant phenolic substances. The meeting was sponsored by the National Science Foundation under the direction of Mr. G. Johnson of Colorado State University, and Dr. Geissman. The papers presented were: "Recent Studies on the Structures and Bitterness of the Flavonoid Glycosides of Citrus" (Dr. R. M. Horowitz, U.S. Department of Agriculture, Albany, California), "Biosynthesis of Plant Phenols" (Dr. S. A. Brown, National Research Council, Saskatoon), "Naturally Occurring Biflavonyls" (Dr. N. Kawano, University of Nagasaki, Japan), "Metabolic Fate of Phenolic Substances in Animals" (Dr. A. N. Booth, U.S. Department of Agriculture, Albany), "Role of Plant Phenolics in Disease Resistance and Immunity" (Dr. I. Uritani, Nagoya University, Japan), "Melanin and its Formation" (Dr. G. A. Swan, University of Durham) and "Estrogenic-like Substances in Plants" (Dr. E. M. Bickoff, U.S. Department of Agriculture, Albany). It is hoped that the proceedings of the symposium will be published.

More than sixty delegates attended the symposium, the last session of which was devoted to founding the Plant Phenolics Group of North America. The officers elected were: president, Dr. S. H. Wender (University of Oklahoma); vice-president, Dr. L. Jurd (U.S. Department of Agriculture, Albany); hon. secretary-treasurer, Dr. V. C. Runeckles.

It was agreed at the first meeting that membership of the Plant Phenolics Group of North America be open to all persons interested in the Group's aims, on applica tion to the secretary, Dr. V. C. Runeckles, P.O. Box 6500, Montreal, Quebec. V. C. RuneckIes

\section{RESEARCH WITH TROPICAL PLANTS}

\begin{abstract}
$\mathrm{T}$ HE Tropical Products Institute of the Department of Scientific and Industrial Research is continuing its work on the examination of plants from tropical territories, and a recent report outlines the scope of investigations carried out during $1960 *$.

Any new sources of drugs could be of great economic benefit to the countries to which the plants are indigenous, and the Institute's activities follows representations from overseas governments for technical assistance in this field. Already 314 plants have been tested, including specimens from North Borneo

* Department of Scientiflc and Industrial Research. The Report of the Tropical Products Institute Committee, with the Report of the Tropical Products Institute. Pp. viii +40. (London: H.M.S.O., 1961.) 38.
\end{abstract}

as well as samples from Kew Gardens. A number of alkaloid-containing plants have been found and are being subjected to further tests. The Director of the Institute reports the expansion of economic and longterm research work by the Institute to meet the needs of rapidly developing tropical countries. This reflects a trend away from short-term inquiries in order to help newly established laboratories overseas with their research and development problems. Even more important is the demand for qualified manpower in the territories themselves, and the Institute has helped by sending visiting scientists to 39 overseas territories and by training research workers from five different tropical countries. More than 900 